\title{
KOMPARASI HASIL BELAJAR MAHASISWA MENGIKUTI KULIAH DARING MATA KULIAH K3 ANTARA MAHASISWA YANG TINGGAL DI KOTA SAMARINDA DAN LUAR KOTA SAMARINDA TAHUN 2021
}

\author{
Gracia Herni Pertiwi ${ }^{1}$, Yovita Erin Sastrini ${ }^{2}$ \\ ${ }^{1,2}$ Program Studi Diploma III Keperawatan Stikes Dirgahayu \\ Samarinda, Alamat : J1. Pasundan nomor 21 Samarinda 74122, Telp \\ (0541) 748335 \\ Email \\ tiwi.curly@yahoo.com
}

\begin{abstract}
ABSTRAK
Penelitian ini menguraikan tentang perbandingan hasil belajar mahasiswa dalam mengikuti kuliah daring antara mahasiswa yang tinggal di Wilayah Kota Samarinda dan di luar Wilayah Kota Samarinda (Pelosok). Tujuan penelitian ini adalah 1) mengetahui hasil belajar mahasiswa yang mengikuti kuliah daring Mata Kuliah K3 di Kota Samarinda, 2) mengetahui hasil belajar mahasiswa yang mengikuti kuliah daring Mata Kuliah K3 di luar Kota Samarinda, 3) mengetahui perbedaan hasil belajar antara mahasiswa yang mengikuti kuliah daring Mata Kuliah K3 di Kota Samarinda dan mahasiswa yang mengikuti kuliah daring di luar Kota Samarinda.Penelitian ini merupakan penelitian komparasi dengan pendekatan kuantitatif. Sampel yang digunakan dalam penelitian ini adalah 15 orang mahasiswa yang berdomisili di Samarinda, dan 15 orang mahasiswa yang berdomisili di luar samarinda yang saat kuliah dilaksanakan tidak berada di Kota Samarinda. Data hasil belajar diperoleh berdasarkan evaluasi hasil belajar mahasiswa pada Mata Kuliah K3 di semester enam. Hasil penelitian menunjukkan bahwa rata-rata nilai mahasiswa yang mengikuti kuliah daring di kota Samarinda adalah 83.27, sedangkan rata-rata nilai mahasiswa yang mengikuti kuliah di luar Kota Samarinda adalah 81.87. Hasil uji hipotesis menggunakan Mann Whitney menunjukkan bahwa tidak ada perbedaan hasil belajar antara mahasiswa yang mengikuti kuliah di wilayah Kota Samarinda dengan mahasiswa yang mengikuti kuliah di luar kota samarinda. Penelitian selanjutnya diharapkan dapat mengembangkan penelitian ini melalui penelitian kualitatif untuk menggali pengalaman mahasiswa dalam mengikuti kuliah daring selama masa Pandemi Covid-19.
\end{abstract}

Kata Kunci : Hasil Belajar, Kuliah Daring.

\section{PENDAHULUAN}

Wabah Corona Virus (Covid-19) yang melanda dunia, menjadi tantangan tersendiri bagi dunia pendidikan secara khusus di perguruan tinggi. Pemerintah telah mengeluarkan larangan untuk berkerumun, pembatasan sosial (social distancing) dan menjaga jarak fisik (physical distancing), menggunakan masker dan selalu mencuci tangan.
Pemerintah melalui Kementerian Pendidikan dan Kebudayaan telah memberikan larangan perguruan tinggi untuk melaksanakan perkuliahan tatap muka (konvensional) dan memerintahkan untuk menyelenggarakan perkuliahan atau pembelajaran secara daring (surat edaran Kemendikbud Dikti Ni.1 tahun 2020). Perguruan tinggi wajib menyelenggarakan 
pembelajaran secara daring atau on-line (firman, F., \& Rahayu, S., 2020)

Bentuk perkuliahan yang dapat dijadikan solusi dalam masa pandemic Covid-19 adalah pembelajaran daring. Menurut Moore, Dikson-Deane, \& Galyen (2011) Pembelajaran daring merupakan pembelajaran yang menggunakan jaringan internet dengan aksesibiltas, konektivitas, fleksibilitas dan kemampuan untuk memunculkan berbagai jenis interaksi pembelajaran. Berdasarkan hasil penelitian yang dilakukan oleh Hia dan Ginting (2020) bahwa ada pengaruh internet terhadap prestasi belajar mahasiswa. Ia menyatakan bahwa pemanfatan internet secara tidak langsung berpengaruh terhadap mahasiswa dalam memanfaatkan internet sebagai media dan sumber belajar, selain itu mahasiswa mendapatkan informasi tanpa batas dalam proses belajarnya dengan memanfaatkan fasilitas yang di dpat melalui internet.

Perpindahan sistem belajar konvensional ke sistem daring merupakan proses pembelajaran yang harus tetap dilaksanakan agar proses pembelajaran dapat berjalan dengan lancar dan mahasiswa juga aktif mengikuti pembelajaran walau sedang dalam kondisi pandemik. Kesiapan mahasiswa dan dosen dalam pelaksanaan pembelajaran daring juga menjadi masalah. Membutuhkan waktu untuk beradaptasi dengan sistem yang baru, sehingga perlu dibuat sistem yang memungkinkan untuk mempermudah keduanya melakukan hal yang baru dalam dunia belajar mengajar.

Terdapat beberapa faktor pendukung dalam proses pembelajaran daring yaitu ketersediaan handphone, kuota dan jaringan internet yang stabil (Hendrastomo, 2008). Koneksi jaringan internet menjadi salah satu kendala yang dihadapi mahasiswa yang tempat tinggalnya sulit untuk mengakses internet, apalagi mahasiswa tesebut tempat tinggalnya di daerah pedesaan, terpencil dan tertinggal, kalaupun ada yang menggunakan jaringan seluler terkadang jaringan internet tidak stabil, karena letak geografis yang masih jauh dari jangkauan sinyal seluler. Pengajaran yang diberikan oleh dosen seyogyanya diterima sama oleh semua mahasiswa, tetapi pada kenyataannya situasi tempat tinggal mahasiswa yang berbeda membuat penerimaan pembelajaran menjadi berbeda antara mahasiswa yang mengikuti pembelajaran di Kota dengan mahasiswa yang mengikuti pembelajaran daring di pelosok. Perbedaan yang paling mencolok adalah jaringan internet yang pada umumnya dikota lebih stabil sedangkan di pelosok tidak stabil, sehingga pembelajaran yang disampaikan dosen dapat diterima secara penuh di kota, sedangkan pembelajaran yang sama seringkali tidak diterima penuh oleh mahasiswa di pelosok karena jaringan yang tidak stabil bahkan tidak ada.

Permasalahan yang kerap terjadi akibat dari jaringan internet yang tidak stabil ini menjadi suatu kendala yang harus dihadapi mahasiswa dalam mengakses internet di tempat tinggalnya apalagi mahasiswa yang tempat tinggalnya berada di daerah pedalaman atau pelosok mengalami masalah saat mengikuti proses pembelajaran secara daring sehingga pelaksanaannya menjadi kurang optimal dan menunjukkan kecenderungan hasil belajar yang berbeda (Sadikin dan Hamidah, 2020).

Berdasarkan gambaran tersebut maka peneliti ingin mengetahui tentang perbedaan hasil belajar mahasiswa yang mengikuti kuliah daring mata kuliah kesehatan dan keselamatan kerja (K3) di kota Samarinda dengan mahasiswa yang mengikuti kuliah daring K3 di luar kota Samarinda (pelosok).

\section{METODE}

Metode yang digunakan dalam penelitian ini adalah Deskriptif Komparatif dengan pendekatan Kuantitatif. Sampel yang digunakan dalam penelitian ini adalah 15 orang mahasiswa yang berdomisili di Samarinda, dan 15 orang mahasiswa yang berdomisili di luar Kota Samarinda yang saat kuliah dilaksanakan tidak berada di Kota Samarinda. Data hasil belajar diperoleh berdasarkan 
evaluasi hasil belajar mahasiswa pada MK

$\mathrm{K} 3$ di semester enam.

\section{HASIL}

A.

istribusi Data Mahasiswa

$\begin{array}{lll}\text { Mahasiswa } & \text { Mahasiswa } \\ \text { di SMD } & \text { di } & \text { Luar }\end{array}$

Samarinda

Frek. Persen Frek. Persen

\begin{tabular}{lcccc}
\hline Perempuan & 12 & 80 & 12 & 80 \\
\hline Laki-laki & 3 & 20 & 3 & 20 \\
\hline Total & 15 & 100 & 15 & 100 \\
\hline
\end{tabular}

Tabel menunjukkan bahwa kedua kelompok memiliki sebaran yang sama yaitu 12 orang mahasiswa perempuan dengan prosentase $(80 \%)$ dan 3 orang mahasiswa laki laki dengan prosentase $20 \%$.

B.

asil Belajar Mahasiswa Yang Mengikuti Kuliah di Kota Samarinda

\begin{tabular}{lc}
\hline $\begin{array}{c}\text { Hasil Belajar } \\
\text { Mahasiswa }\end{array}$ & $\begin{array}{c}\text { Mahasiswa Mengikuti } \\
\text { kuliah Daring di Smd }\end{array}$ \\
\hline Minimum & 80 \\
\hline Maximum & 90 \\
\hline Mean & 83.27 \\
\hline Std. Deviasi & 2.81 \\
\hline
\end{tabular}

Nilai rata-rata prestasi belajar mahasiswa yang mengikuti kuliah daring dari Kota Samarinda adalah 83.27. Nilai prestasi belajar terendah adalah 80.00 dan nilai tertingginya 90.00

\section{Hasil Belajar Mahasiswa Yang Mengikuti Kuliah di Luar Kota Samarinda.}

\begin{tabular}{lc}
\hline $\begin{array}{c}\text { Hasil Belajar } \\
\text { Mahasiswa }\end{array}$ & $\begin{array}{l}\text { Mahasiswa } \\
\text { Mengikuti } \\
\text { kuliah Daring } \\
\text { di Smd }\end{array}$ \\
\hline Minimum & 78 \\
\hline Maximum & 80 \\
\hline Mean & 81.87 \\
\hline Std. Deviasi & 2.35 \\
\hline
\end{tabular}

Nilai rata-rata prestasi belajar mahasiswa yang mengikuti kuliah daring dari daerah pedalaman adalah 81.87. Nilai prestasi belajar terendah adalah 78.00 dan nilai tertingginya 85.00

\begin{tabular}{lc}
\hline & \multicolumn{2}{c}{$\begin{array}{l}\text { Hasil } \\
\text { Mahasiswa }\end{array}$} & Belajar \\
\hline $\begin{array}{l}\text { Asymp. Sig. } \\
\text { (2-tailed) }\end{array}$ & 0.187 \\
\hline
\end{tabular}

Berdasarkan hasil pengolahan data diperoleh nilai sig. (2-tailed) $=0.187$, dengan demikian maka dapat diinterpretasikan bahwa tidak terdapat

H perbedaan signifikan antara hasil belajar mahasiswa yang mengikuti kuliah daring di kota samarinda dengan mahasiswa yang mengikuti kuliah daring di luar kota Samarinda.

\section{E. DISKUSI HASIL PENELITIAN}

Berdasarkan analisis dapat dilihat bahwa hasil belajar mahasiswa yang -mengikuti kuliah secara daring di Wilayah Kota Samarinda dengan mahasiswa yang mengikuti kuliah secara daring di luar Wilayah Kota Samarinda (pelosok) terdapat sedikit perbedaan. Hal ini ditunjukkan dengan nilai hasil belajar ratarata mahasiswa yang mengikuti kuliah secara daring di kota samarinda sebesar 83.27 dengan nilai tertinggi 90 dan terendah 80, sedangkan nilai rata-rata mahasiswa yang mengikuti kuliah secara daring di luar Wilayah Kota Samarinda (pelosok) nilai rata-rata sebesar 81.87 dengan nilai tertinggi 80 dan nilai terendah 78. Perbedaan nila rata-rata kedua kelompok mahasiswa tersebut adalah 1.4.

Berdasarkan hasil analisis deskriptif diketahui bahwa hasil belajar mahasiswa yang mengikuti kuliah secara daring di Wilayah Kota Samarinda memiliki hasil belajar yang lebih tinggi dibandingkan dengan hasil belajar mahasiswa yang 
mengikuti kuliah secara daring di luar Wilayah Kota Samarinda (Pelosok). Hal ini disebabkan oleh karena pembelajaran yang disampaikan dosen seringkali tidak diterima secara lengkap karena jaringan signal yang terputus di tengah-tengah proses pembelajaran daring.

Berdasarkan hasil analisis statistik menggunakan uji Mann-Whitney menunjukkan bahwa tidak terdapat perbedaan yang signifikan antara hasil belajar antara mahasiswa yang mengikuti kuliah Mata Kuliah K3 secara daring di Kota Samarinda dengan mahasiswa yang mengikuti kuliah daring di Luar Wilayah Kota Samarinda (Pelosok).

Berdasarkan hasil pengamatan yang dilakukan selama proses pembelajaran daring berlangsung, mahasiswa selalu tepat waktu mengikuti materi perkuliahan yang disampaikan oleh dosen. Kondisi letak geografis tempat mahasiswa tinggal tidak menyurutkan mereka untuk ikut aktif dalam setiap proses pembelajaran yang berlangsung, di satu sisi kendati situasi pandemi mengharuskan mahasiswa untuk kuliah secara daring, namun mereka siap untuk menghadapi situasi baru dan perkuliahan dengan metode yang baru, mengembangkan kreatifitas mereka dengan memaksimalkan penggunaan smartphone yang tidak terbatas hanya untuk komunikasi tetapi juga sebagai sarana untuk belajar.

Adjani, dkk (2013) menyatakan bahwa motivasi belajar berpengaruh positif terhadap prestasi belajar mahasiswa karena ketika mahasiswa mempunyai minat pada satu mata kuliah tertentu, maka ia akan cenderung focus dan memberikan hasil yang positif terhadap prestasi belajarnya, hal ini disebabkan oleh adanya motivasi yang tinggi sehingga memperbesar usaha dan kegiatannya untuk mencapai prestasi belajar yang baik.

Walaupun mereka berada di tempat yang jauh dari kota (Pelosok), namun mereka tidak kehilangan semangat, dalam keadaan terbataspun mereka tetap berkreativitas dalam belajar. Berdasarkan penelitian Nurfitriyani (2014) diperoleh data bahwa kreativitas mahasiswa berpengaruh terhadap hasil belajar mahasiswa. Secara parsial, pengaruh kreativitas mahasiswa terhadap hasil belajar sebesar $46.6 \%$, sejalan dengan penelitian Supardi (2012 dalam Nurfitriyani, 2014) bahwa terdapat pengaruh positif antara berpikir kreatif terhadap prestasi belajar mahasiswa. Mahasiswa yang kreatif cenderung tidak mudah menyerah dan menyelesaikan persoalan yang dihadapinya. Demikian halnya dengan mahasiswa yang tinggal di luar samarinda (Pelosok), Mahasiswa berusaha untuk tetap belajar dan menghadapi kendala. Salah satu kendala yang dihadapi di daerah pelosok adalah sulitnya mendapatkan signal yang bagus, bahkan jaringan signal hanya ada di titiktitik tertentu yang mampu dijangkau oleh smartphone. Mahasiswa tidak menyerah dan berusaha mencari spot signal yang bagus agar mereka tetap bisa mengikuti kuliah daring dengan konsekuensinya adalah mereka harus mencari tempattempat yang memiliki signal yang kuat dan stabil..

Berdasarkan pengalaman mereka, kadangkala di rumah mereka signal tidak stabil, sehingga mereka harus pergi mencari tempat-tempat yang memiliki jaringan signal yang stabil untuk dapat belajar. Hal ini menandakan bahwa semangat mereka tidak kendor walaupun menghadapi keterbatasan, dan jauh dari kota. Ini juga menandakan bahwa mereka sungguh-sungguh mau belajar, tetap semangat dan mereka tidak dilemahkan oleh situasi, tempat atau keterbatasan. Hal ini menunjukkan bahwa mereka tidak pernah menyerah dan perjuagan mereka untuk tetap belajar, kesulitan tidak menghambat mereka tetapi menjadi pendorong untuk tetap memperoleh pendidikan/ pengetahuan. Mereka juga menjadi kreatif untuk tetap dapat belajar, karena bila mereka tidak kreatif, mereka tidak akan dapat belajar. Bantuan Pemerintah juga ikut membantu meringankan beban pengeluaran pendidikan mahasiswa melalui pemberian kuota bagi mahasiswa, sehingga mereka lebih tenang dalam mengikuti Kuliah K3 
Secara daring. menghadapi perkuliahan walaupun dilaksanakan secara daring. Kreatifitas mereka bergembang ketika mereka mendapatkan kesulitan sehingga mereka dapat menyelesaikan mata kuliah K3 sesuai dengan jadwal yang telah ditentukan dengan hasil belajar yang tidak jauh berbeda dengan mahasiswa yang mengikuti kuliah secara daring di Kota Samarinda.

\section{F. PENUTUP}

\section{Kesimpulan}

a) Hasil belajar mahasiswa yang mengikuti kuliah daring di kota Samarinda memiliki rata-rata nilai 83.27

b) Hasil belajar mahasiswa yang mengikuti kuliah di luar Wilayah Kota Samarinda (pelosok) adalah 81.87

c) Tidak terdapat perbedaan yang signifikan antara hasil belajar antara mahasiswa yang mengikuti kuliah K3 secara daring di Wilayah Kota Samarinda dengan mahasiswa yang mengikuti kuliah daring di Luar Wilayah Kota Samarinda (Pelosok)

\section{Saran}

a) Mahasiswa mempertahankan semangat belajar agar tidak kendor, mengembangkan kreatifitas

b) Sebagai tenaga pendidik hendaknya mengusahakan metode-metode yang menarik sehingga mahasiswa tidak merasa bosan dan berperan aktif dalam proses pembelajaran secara daring

c) Peneliti selanjutnya diharapkan dapat mengembangkan penelitian ini melalui penelitian kualitatif untuk menggali pengalaman mahasiswa dalam mengikuti kuliah daring selama masa Pandemi Covid-19

\section{G. DAFTAR PUSTAKA}

Adjani, Dkk. (2013). Faktor-Faktor yang Mempengaruhi Prestasi Belajar Mahasiswa pada Mata Kuliah Pengantar Akuntansi. Jurnal Ilmiah Mahasiswa FEB Universitas Brawijaya. Vol. 1 No.1.

Astuti, P., \& Febrian, F. (2019). Blended Learning Syarah: Bagaimana Penerapan dan Persepsi Mahasiswa. Jurnal Gantang, 4(2), 111-119. https://doi.org/10.31629/jg.v4i2.156 $\underline{0}$

Bell, D., Nicoll, A., Fukuda, K., Horby, P., Monto, A., Hayden, F., ... Van Tam, J. (2006). Nonpharmaceutical interventions for pandemic influenza, national and community measures. Emerging Infectious Diseases. https://doi.org/10.3201/eid1201.051 $\underline{371}$

Dahlan, S. 2001, Statistik untuk Kedokteran dan Kesehatan, PT. Salemba Medik

Darmalaksana, W. (2020). WhatsApp Kuliah Mobile . Fakultas Ushuluddin UIN Sunan Gunung Djati Bandung.

Firman, F., \& Rahayu, S. (2020). Pembelajaran Online di Tengah Pandemi Covid-19. Indonesian Journal of Educational Science (IJES), 2(2), 81-89.

Hendrastomo, G. (2008). Dilema dan Tantangan Pembelajaran Elearning 1 (The Dilemma and the Challenge of. Majalah Ilmiah Pembelajaran, 4, 1-13.

Hia, N., \& Ginting, S. (2020). Pengaruh Internet Terhadap Prestasi Belajar mahasiswa Fakultas Ekonomi dan Ilmu Sosial Universitas sari Mutiara Indonesia Kota Medan. Jurnal Lensa Mutiara Komunikasi, ISSN: 2579-8332.

Moore, J. L., Dickson-Deane, C., \& Galyen, K. (2011). E-Learning, online 
learning, and distance learning environments: Are they the same? Internet and Higher Education. https://doi.org/10.1016/jiheduc.201 0.10 .001 .

Nurfitriyani, M. (2014). Pengaruh Kreativitas Dan Kedisiplinan Mahasiswa Terhadap Hasil Belajar Kalkulus. Jurnal Formatif 4(3): 219-226

Sadikin, A., \& Hamidah, A. 2020. Pembelajaran Daring, ISSN 2580-0922 (online) Diakses tanggal 22

Mei 2021 